Between thirty and forty genera of corals and well over one hundred species are concerned with the formation of these reefs. Probably no region in the world is so rich in coral species. They are assisted in their building action by coralline algæ, Lithothamnia, and by the minute calcareous skeletons of foraminiferans, and also to a smaller extent by the dead shells of molluscs-foremost amongst which is the giant clam, Tridacna gigas, which may attain a length of four and a half feet and a weight of four or five hundredweight. The growth of corals, the study of which formed an important part of the programme of the expedition, is greater than might be expected, certain species doubling their size in six months. Such powers of growth are necessary, however, if the reefs are even to maintain themselves. 'They are continually being battered by the seas, they are subject to the destructive action of a host of molluses and worms which bore through their skeletons until these are honeycombed with their tunnels, and even algæ play some part in this destructive process. Exposure during low spring tides invariably kills corals which have grown above a certain height, thus maintaining the level surface of the summit of the reefs. Near the coast the fringing reefs are in constant danger of being destroyed by great floods of fresh water running off from the land during the summer rainy season. A striking example of this was furnished in 1918 when Stone Island Reef near Bowen was completely destroyed after 36 inches of rain had fallen in eight days.

The nature of communities known as coral reefs is too great a subject to discuss here; a detailed census of the population of different reefs and different zones of them was undertaken by the expedition. Corals themselves, it was found after careful studies, live on the minute floating animal life of the seas-the zooplankton-for the capture and digestion of which they are admirably equipped. They contain within their tissues vast numbers of minute algæ, zooxanthellæ, which dispose of the waste products of coral metabolism, and provide, as a result of their photosynthetic activities, abundant supplies of oxygen (possibly of vital importance in view of the density of the population on a typical reef), but do not, as has been thought, play any great part-if any at all, the matter is still sub judice-in the nutrition of the coral.

The conditions in the seas which bathe the reefs are of primary importance; they control the food supply and the 'climate'. The changes in the physical condition and in the principal chemical constituents-notably those which can be utilised as food by plant life-are far smaller than occur in temperate seas. The plant and animal plankton is also much poorer and shows fewer fluctuations, but there is no reason to doubt that the latter provide all the food required by the corals, which, in spite of their apparent bulk, are really thin sheets of living matter spread over a great surface of calcareous skeleton. Life on the sea bottom, as revealed by dredging and trawling, is abundant where the bottom is rocky or sandy, but very poor in the inner parts of the platform where it is covered with a soft mud. Fish, not unnaturally, are abundant in the former regions and scarce in the latter.

The reefs are a source of both profit and loss to Australia. They are rich in a number of com. mercially valuable animals, notably pearl shellthe smaller black - lip (Pinctada margaratifera) everywhere and the large gold-lip ( $P$. maxima) in the Torres Strait and farther west-the large Trochus shell from which pearl buttons are made, edible oysters of various kinds, bêche-de-mer (Holothurians), both edible and tortoise-shell turtles, dugong, many kinds of fish, while sponges of some commercial value are present. In its capacity as a breakwater the Barrier Reef has gained for the enclosed steamer channel the title of Australia's Grand Canal, but it is a canal full of dangers from reefs and, in the summer, from cyclones, and loss from shipwreck forms a very serious item in the debit account.

3 Geographical Journal, vol. 74, Nos. 3 and 4, 1929.

\title{
The Discovery of a Second Braincase of Sinanthropus.
}

By Prof. G. Elıiot Sмiтh, F.R.S.

$\mathbf{A}^{\mathrm{T}}$ $T$ a meeting of the Geological Society of China in the last week of July, Prof. Davidson Black announced the discovery of another skull of Peking man.

In NATURE of Mar. 22, 1930 (p. 448), an account was given of the discovery of a series of remains of Sinanthropus culminating in the recovery of an almost complete braincase by Mr. W. C. Pei on Dec. 2, 1929, while clearing a sheltered recess of the main deposit at Chou Kou Tien. Some days (Oct. 28) before this skull was found, five human teeth were recovered from a spot higher up in the shaft (locus $D$ of the excavators' report), where they were associated with the skull of a large deer and some pieces of fossilised bone and blocks of stone, which were brought to the laboratory in Peking for examination.

This material was 'developed' during the third week in June by the technical assistants working under Prof. Davidson Black's supervision, and he found that there were enough fragments, which fitted together, to form the greater part of another uncrushed skull of Sinanthropus. He waited until the return to Peking of Dr. Wong (Wong Wen Hao), the Director of the Survey, before making the public announcement of his important discovery.

For reasons which are not yet clear to those who have not seen the actual specimens, Prof. Davidson Black regards the skull found on Dec. 2, 1929, as that of a young woman, and the calvaria the discovery of which is now reported is in his opinion that of a young adult male. It conforms to the same general type as the skull previously found, and its proportions are similar. But the braincase is not so thick and the frontal eminences not so pronounced. The most interesting new fact revealed in this

$$
\text { No. 3171, VoL. 126] }
$$


discovery is the nature of the root of the nose, which is broad and flat and quite unlike that of Piltdown man.

The newly discovered skull was found in association with a number of teeth which can be assumed to have belonged to the same individual. This fact adds to the interest of two mandibles found in 1928 in association with the crushed parts of the respective braincases.

The remains of four skulls of Sinanthropus and teeth of at least six other individuals have so far been found. Thus there is available for study in China a much richer material of early Pleistocene man than the fragments of the individual specimens of Pithecanthropus and Eoanthropus provide. Moreover, the geological age of the Chinese fossils can be established with more certainty than that of the other two primitive genera, which are assumed to be roughly contemporaneous.

The fossils from Java and Sussex were found in gravels, where they had been deposited by running water. Although there is little doubt which of the heterogeneous fossils found in these gravels were contemporaneous with the human remains, in the case of the men of Peking, who left their bones in the cave where they lived, there is less room for doubt that the bones of animals deposited alongside them provide more certain data for the estimation of their geological age. Thus the claim made by
Pére Teilhard de Chardin and Dr. C. C. Young that Sinanthropus lived in Lower Pleistocene times rests upon a surer foundation than the similar claims that have been made in the cases of Pithecanthropus and Eoanthropus.

Further, the conditions under which the discoveries are being made at Chou Kou Tien hold out a greater promise of further evidence than in the cases where the fossils have been scattered by running water. Thus a series of fragments have already been recovered every autumn since the type tooth was recovered in 1927, and it is not unreasonable to expect that much more still remains to be found in this cave, and possibly in other fossil beds in the neighbourhood. So far no worked tools have been found in the cave ; but if such should be recovered, their association with the human remains will be less uncertain than in the case of the other Pleistocene men's implements.

For these reasons, in addition to the intrinsic interest and morphological significance of the skulls of Sinanthropus, the discoveries in China have an importance which is unique. It is a matter for congratulation that the investigation of this site should have fallen into such competent hands and that ample facilities and skilled assistance should be available for the work, which is being conducted with great thoroughness and insight.

\section{News and Views.}

Prof. Elliot Smith's announcement in another column of this issue that Dr. Davidson Black has reconstructed still another skull of Peking man from material obtained from the now famous cave of Chou Kou Tien is assuredly welcome though perhaps not entirely surprising. Four skulls and teeth belonging to probably six individuals have now been obtained from this source, and it is therefore evident that the fortunate explorers have lighted upon what must have been the final resting place and perhaps the home of a family group or horde of this type of early man. So far, no implements have been found which would determine the cultural horizon of Peking man, but the conditions of discovery are such as to afford grounds for hope. It is at any rate fortunate that the association of the remains with fossilised bones of animals assigned with some confidence to the Lower Pleistocene appears to place the date beyond question. Dr. Davidson Black has pronounced his latest skull to be that of a young adult male, while that found in December last is said to be that of a young woman. Comparative study of the two will no doubt be fruitful of results. A first inspection of the new skull has already yielded a new character of the nose in which it presents a marked difference from the Piltdown skull. A more detailed examination of the two skulls than is yet possible will be necessary before it can be determined what are the precise relationships of Peking man and other early types. It is already clear, however, that these remains will make possible a further advance in the reconstruction of man's ancestral forms. Prof. Elliot Smith is sailing for
China on Aug. 14, and in this connexion the results of his personal examination of the material will be awaited with the keenest interest.

In the interesting little church at Longfield, Kent, close to Fawkham Station, is to be seen the memorial window erected by some members of the University of Cambridge to the memory of Dr. Thomas Plume, the founder of the Plumian professorship of astronomy, of which $\operatorname{Sir}$ A. S. Eddington is the present holder. Though never rector of Longfield, Plume for many years lived at Longfield Court, just behind the church, and he died there on Nov. 24, 1704. At his death Plume was seventy-four years of age, having been born just three hundred years ago, in the summer of 1630 . The exact date of his birth does not appear to be known, but he was baptised on Aug. 18, 1630, in All Saints' Church, Malden, Essex, of which place his father was an alderman. Educated first at Chelmsford Grammar School, Plume entered Christ's College, Cambridge, and at the age of nineteen took the degree of M.A. Entering the Church, in 1658 he was made vicar of Greenwich, a living then in the gift of Richard Cromwell, and both Pepys and Evelyn speak of his excellent preaching. This important living he held tor the remainder of his life, but from 1679 onward was also Archdeacon of Rochester.

LIKE Lucas and Lowndes, the founders of two other famous professorships at Cambridge, Plume did not add to mathematical or astronomical knowledge, but he lived in an age when among men of education

No. 3171, VoL. 126] 